\title{
Studi Warna Biji Jagung Lokal Madura Menggunakan Teknologi Imaging
}

\author{
Study Kernel Colours of Local Maize Varieties from Madura Using Imaging Technology
}

\author{
Nurholis $^{1 *}$, Mohammad Syafii ${ }^{1}$, Syaiful Khoiri ${ }^{1}$ \\ Prodi Agroteknologi Fakultas Pertanian Universitas Trunojoyo Madura \\ Jl. Raya Telang PO BOX 2 Kamal Bangkalan Madura \\ *Email korespondensi: nurholis_xtr28@yahoo.com
}

Diterima: 27 Januari 2020 / Disetujui: 19 Februari 2020

\begin{abstract}
Maize is an important crop as third of staple food in the world. It is also an alternative food substitute for rice in order to support food diversification program in Indonesia. The purpose of this study was to determine the diversity of corn germplasm based on seed color and its quantification. This research was conducted in August-October 2018, exploration was carried out in four districts namely Bangkalan, Sampang, Pamekasan, and Sumenep. The results of the exploration activities obtained 60 accessions of local corn, 44 genotypes and 16 genotypes as bulk population wad obtained. Based on the results of imaging approach using ImageJ tools for the beta-carotene and anthocyanin study populations, there were consistent results based on the results of $3 D$ histograms and corrplots. The results of this study indicate that the color quantification of corn kernels can be done through an imaging approach using the ImageJ device.
\end{abstract}

Keywords: corn, madura, imageJ, variety

\section{ABSTRAK}

Jagung merupakan komoditas penting yang merupakan pangan pokok ketiga yang paling bayak dikonsumsi penduduk dunia serta merupakan bahan pangan alternatif pengganti beras dalam rangka mendukung program diversifikasi pangan di Indonesia. Tujuan penelitian ini untuk mengetahui keragaman plasma nutfah jagung terutama pada warna biji dan kuantifikasinya. Penelitian ini dilakukan pada bulan Agustus-Oktober 2018, kegiatan eksplorasi di lakukan di empat kabupaten yaitu Bangkalan, Sampang, Pamekasan, dan Sumenep. Hasil dari kegiatan eksplorasi diperoleh 60 aksesi jagung lokal, 44 masih dalam bentuk tongkol dan 16 dalam bentuk jagung pipil populasi bulk. Berdasarkan hasil imaging menggunakan perangkat ImageJ untuk populasi studi betakaroten maupun antosianin menunjukkan hasil yang konsisten baik berdasarkan hasil 3D histogram maupun corrplot. Hasil penelitian ini menunjukkan bahwa kuantifikasi warna biji jagung dapat dilakukan melalui pendekatan imaging menggunakan perangkat ImageJ.

Kata kunci: jagung, madura, imageJ, varietas

\section{PENDAHULUAN}

Jagung merupakan komoditas penting yang merupakan pangan pokok ketiga yang paling bayak dikonsumsi penduduk dunia (Kumar et al., 2014). Diantara tanaman serealia jagung menempati urutan ketiga setelah padi dan gandum terutama di Asia dan Afrika. Selain digunakan sebagai bahan pangan, jagung juga dimanfaatkan sebagai pakan serta bahan mentah untuk berbagai kegiatan industri (Chaudary et al. 2014).

Jagung mengandung pro vitamin A karotenoid dengan keragaman genetik tinggi. Hal ini membuat jagung menjadi kandidat pangan pokok yang baik untuk biofortifikasi tanaman (Kumar et al., 2014). Lebih lanjut Jittham et al. (2017) mengemukakan bahwa peningkatan kandungan karotenoid kernel jagung merupakan prioritas pemulia terkaittujuan pemuliaan dengan luaran berupa nutrisional biofortifikasi. Muthusamy et al. (2015) melaporkan bahwa terdapat keragaman genetic untuk berbagai karotenoid jagung lokal dan menunjukkan bahwa zeaxanthin dan lutein merupakan karotenoid dominan.

Data pendahuluan mengindikasikan bahwa seleksi visual untuk jagung berwarna jingga tua dalam program pemuliaan tanaman jagung meningkatkan kandungan pro vitamin A (Chandler et al., 2013). Warna kernel berbeda menentukan kandungan karotenoid ataupun kandungan antosianin pada tanaman jagung. Jagung berwarna jingga mengandung betakaroten, sedangkan jagung berwarna kuning lemon, ungu, dan biru terang tidak mengandung beta karoten. Jagung berwarna putih memiliki total flavonoid terendah dibandingkan jagung berwarna merah ataupun ungu. Jagung dengan warna kernel merah dan ungu memiliki kandungan flavonoid lebih rendah dibandingkan kuning lemon, kuning, dan jingga (Zilic et al., 2012). Warna 
yang sama namun varietas berbeda ternyata menghasilkan jumlah antosianin yang berbeda. Tidak seperti komposisi padi hitam dan merah yang memiliki profin antosianin yang simple, jagung, pink, ungu dan merah mengandung profil yang kompleks (Abdel-Aal et al., 2006). Owens et al. (2014) menduga bahwa galur yang memiliki warna endosperma kuning atau jingga yang lebih gelap perlu untuk diseleksi. Meskipun demikian Rodriguez et al. (2013) melaporkan bahwa hubungan kandungan pigmen dan kapasitas anti oksidan tidak selalu linear, meskipun normalnya warna lebih gelap memiliki kapasitas anti oksidan lebih besar.

Sebagai salah satu sentra produksi jagung di Indonesia, Madura juga memiliki keragaman besar terkait dengan warna biji. Beberapa penelitian sebelumnya telah menyebutkan bahwa kandungan betakaroten maupun antosianin bergantung dari warna biji. Sehingga perakitan pangan fungsional kaya akan betakaroten dan antosianin dengan memanfaatkan plasma nutfah lokal Madura menjadi penting untuk dilakukan disamping peningkatan produksi. Jagung yang memiliki gradasi warna mulai dari putih sampai merah keunguan dapat dikuantifikasi dengan menggunakan teknologi imaging. Phenotyping dilakukan menggunakan pendekatan imaging menggunakan program ImageJ. Penggunaan teknologi imaging untuk mengkuantifikasi warna jagung berdasarkan parameter RGB, R, G, dan B menggunakan perangkat ImageJ diharapkan mampu membedakan gradasi warna pada masing-masing warna biji jagung hasil ekplorasi..

\section{BAHAN DAN METODE}

Penelitian ini dilakukan pada bulan Agustus-Oktober 2018, kegiatan eksplorasi di lakukan di empat kabupaten yaitu Bangkalan, Sampang, Pamekasan, dan Sumenep. Jagung-jagung hasil eksplorasi kemudian dilakukan phenotyping untuk mengkuantifikasi derajat warna pada masing-masing aksesi. Pada kegiatan phenotyping digunakan 60 aksesi yang didasarkan pada perbedaan warna, lokasi, dan juga jenis jagung yang digunakan. Untuk tujuan studi hubungan warna dengan kandungan antosianin, dilakukan pengambilan 10 aksesi jagung dengan pertimbangan tidak adanya pengaruh metaksania. Jagung yang terpilih adalah jagung yang memiliki gradasi warna mulai dari putih sampai merah keunguan. Phenotyping dilakukan menggunakan pendekatan imaging menggunakan program ImageJ sesuai dengan metode yang dikembangkan oleh Nugroho (2018). Pengambilan gambar dilakukan di studio mini dengan perangkat kamera Fuji Film Fineplix S2980 mode manual dengan exposure F 4.0, shutter speed 40, dan ISO100. Pencahayaan studio mini menggunakan lampu Phillips 9 watt sebanyak dua buah dengan jarak pengambilan ke objek secara vertical $40 \mathrm{~cm}$.

\section{HASIL DAN PEMBAHASAN}

\section{Kegiatan eksplorasi}

Kegiatan eksplorasi dilakukan dalam upaya mendapatkan sebanyak mungkin informasi terkait keragaman tanaman jagung yang ada di Madura. Kegiatan eksplorasi telah dilakukan di empat kabupaten yaitu Bangkalan, Sampang, Pamekasan dan Sumenep. Kegiatan eksplorasi dipusatkan pada daerah yang mayoritas penduduknya masih menanam jagung lokal.

Lokasi dalam kegiatan eksplorasi disajikan pada Tabel. Daerah di Kabupaten sumenep merupakan yang paling banyak dijadikan sebagai lokasi eksplorasi yaitu sebanyak tujuh lokasi, sedangkan daerah di Kabupaten pamekasan merupakan daerah dengan lokasi paling sedikit yaitu satu lokasi. Mendominasinya daerah sumenep sebagai lokasi paling banyak dilakukan eksplorasi dikarenakan masih banyaknya masyarakat yang menanam jagung lokal dibandingkan tiga kabupaten lain. Selain itu keragaman yang begitu besar terkait dengan jenis jagung dan morfologi serta warna kernel jagung menjadi pertimbangan berikutnya.

Tabel 1. Lokasi kegiatan eksplorasi dan karakterisasi hubungan karakter warna kernel dengan kandungan betakaroten dan antosianin

\begin{tabular}{lll}
\hline No & Lokasi & Koordinat \\
\hline 1 & Gaddhu Timur, Kecamatan Gandhing Sumenep & $-7.001050,113.731334$ \\
2 & Kecamatan Manding Sumenep & $-6.966768,113.849845$ \\
3 & Sema'an, Kecamatan Dasuk Sumenep & $-6.911036,113.793929$ \\
4 & Ketawang Laok, Kecamatan Guluk-Guluk Sumenep & $-7.048895,113.685061$ \\
5 & Desa Rombiyah, Kecamatan Ganding & $-7.058178,113.704983$ \\
6 & Desa Timur Jenjang (jagung merah) Kecamatan Kangayan & $-6.846258,115.396036$ \\
7 & Desa Daandung Kecamatan Kangayan & $-6.853544,115.352667$ \\
8 & Desa Kretek kecamatan pademawu pamekasan & $-7.197232,113.512796$ \\
9 & Taddan, Kecamatan Camplong Kabupaten Sampang & $-7.213856,113.274078$ \\
1 & Desa Gunung Rancak Kabupaten Sampang & $-6.981242,113.308899$ \\
1 & Desa Keleyan Kecamatan Socah Kabupaten Bangkalan & $-7.082639,112.712943$ \\
\hline
\end{tabular}




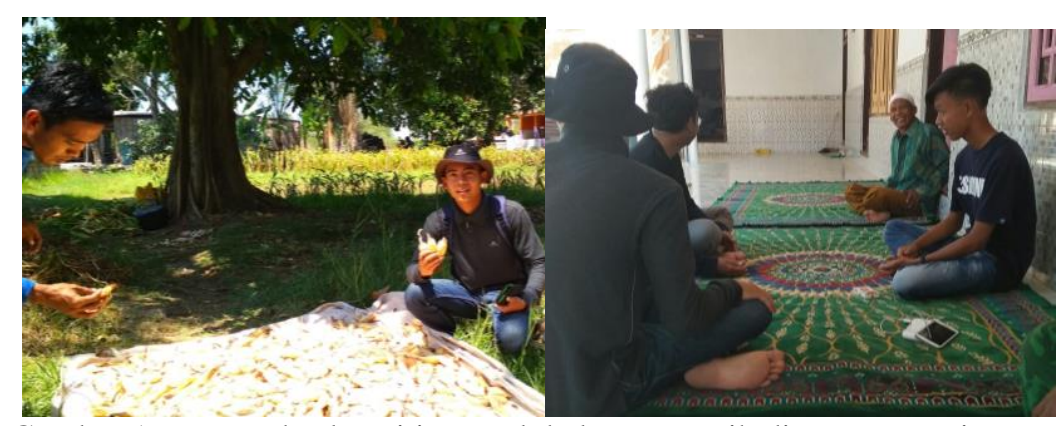

Gambar 1. Proses eksplorasi jagung lokal yang masih ditanam petani

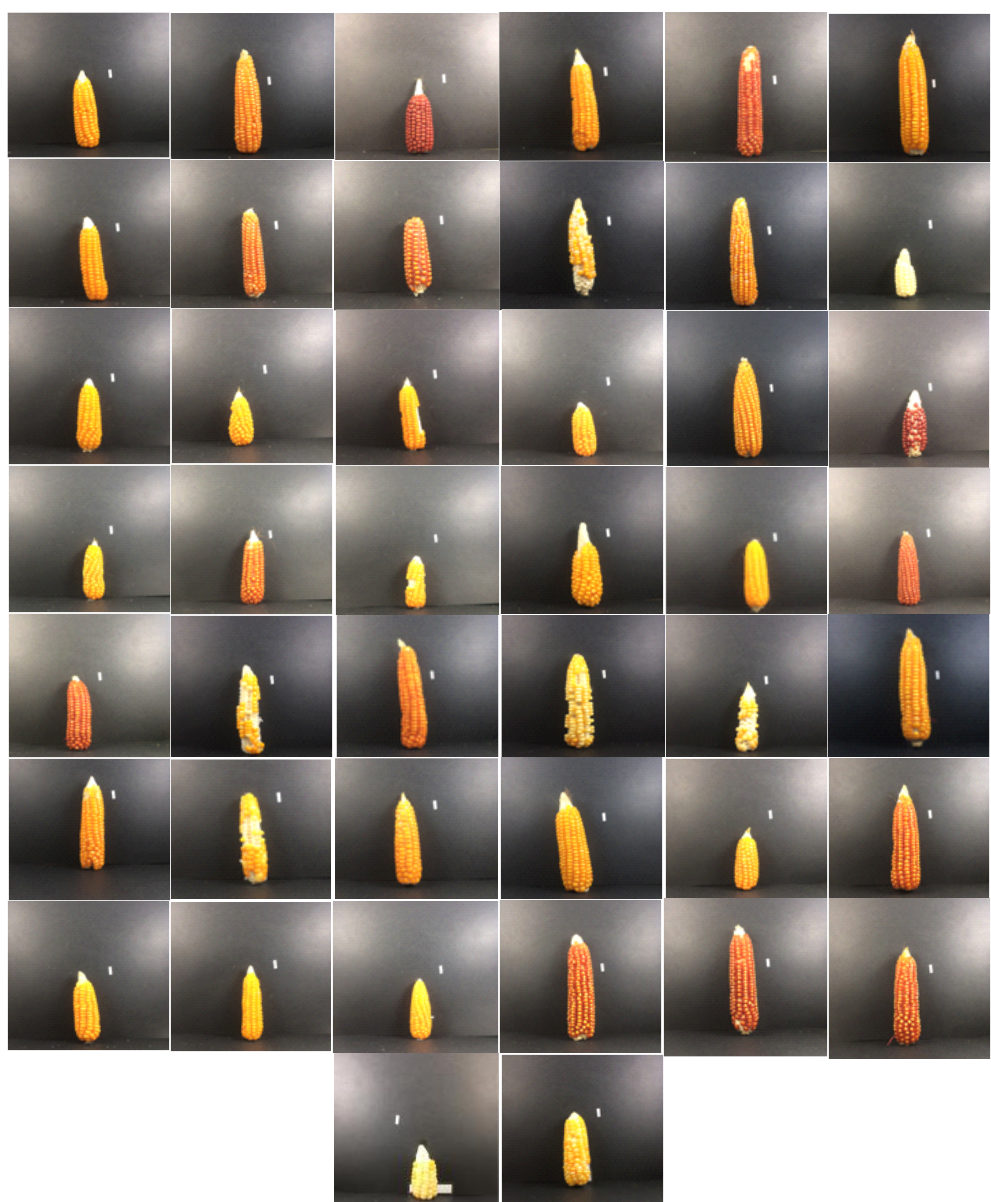

Gambar 2. Ragam bentuk tongkol dan warna biji jagung lokal hasil eksplorasi

Kegiatan eksplorasi dilakukan pada bulan kering di mana sebagian besar masyarakat sudah melakukan pemanenan, sehingga pengamatan keragaman hanya bisa dilakukan berdasarkan karakter morfologi tongkol dan biji. Untuk mendapatkan informasi lebih lanjut, dilakukan kegiatan wawancara dengan pemilik lahan terkait dengan sejarah penggunaan lahan (Gambar 1). Hal tersebut dikarenakan tanaman jagung merupakan tanaman menyerbuk sendiri, sehingga informasi mengenai sejarah penggunaan lahan menjadi penting diketahui untuk meminimalisasi cemaran jagung lain selain populasi jagung lokal eksisting setempat.
Dari hasil eksplorasi ini diperoleh 44 tongkol jagung yang dipilih berdasarkan perbedaan morfologi tongkol dan juga warna kernel, serta 16 genotipe dalam bentuk bulk. Keragaman antar aksesi dapat dilihat dari bentuk dan ukuran tongkol (Gambar 1). Hal ini menunjukkan bahwa kegiatan eksplorasi ini telah berhasil mengkoleksi jagung lokal Madura dengan berbagai baground genetik yang berbeda. Hal ini menjadi dasar dan awal yang baik untuk melakukan studi mengenai hubungan antara warna jagung dan kandungan antosianin dalam rangka pengembangan harvest plus melalui biofortifikasi. 


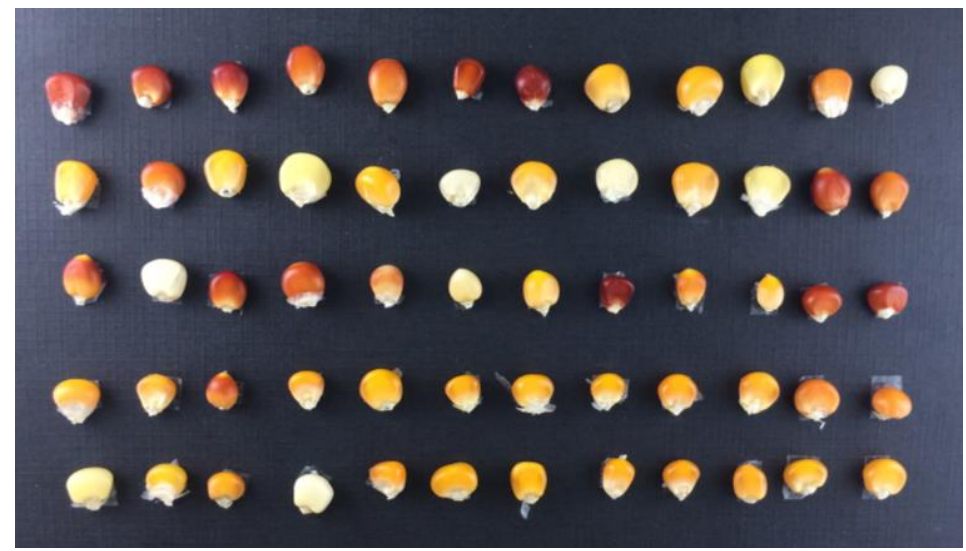

Gambar 3. Ragam warna dan bentuk jagung lokal hasil eksplorasi

Tabel 2. Kisaran nilai setiap warna biji jagung setiap peubah

\begin{tabular}{lllll}
\hline & RGB & R & G & B \\
\hline M1 & $53.8-38.7$ & $50.4-71.3$ & $50.4-75.7$ & $34.8-49.6$ \\
M2 & $13.0-17.7$ & $30.0-37.8$ & $11.0-17.4$ & $6.3-9.8$ \\
M3 & $8.0-14.3$ & $14.1-28.8$ & $6.6-14.2$ & $7.5-12.8$ \\
M5 & $17.9-30.9$ & $38.8-52.6$ & $20.5-39.7$ & $6.3-20.0$ \\
M6 & $20.5-32.5$ & $42.7-58.6$ & $26.8-45.0$ & $6.0-19.8$ \\
M7 & $38.2-47.2$ & $49.0-64.4$ & $49.1-67.7$ & $33.8-53.8$ \\
M9 & $10.6-22.3$ & $23.7-37.3$ & $7.6-22.2$ & $6.4-19.2$ \\
M10 & $8.2-11.5$ & $16.1-24.1$ & $5.6-10.7$ & $5.4-8.7$ \\
M11 & $15.6-26.2$ & $36.0-54.3$ & $14.9-33.8$ & $6.9-18.3$ \\
M12 & $10.0-7.0$ & $12.6-17.2$ & $5.1-9.4$ & $6.4-10.0$ \\
\hline
\end{tabular}

\section{Phenotyping jagung lokal Madura}

Jagung-jagung hasil eksplorasi kemudian dilakukan phenotyping untuk mengkuantifikasi derajat warna pada masing-masing aksesi. Pada kegiatan phenotyping digunakan 60 aksesi yang didasarkan pada perbedaan warna, lokasi, dan juga jenis jagung yang digunakan. Dari gambar terlihat bahwa keragaman antar aksesi tidak hanya berdasarkan warna kernel saja, namun keragaman bentuk dan ukuran biji.

Jagung yang diperoleh dari hasil eksplorasi ini terbukti memiliki keragaman yang besar terkait dengan warna kernelnya. Warna aksesi jagung yang diperoleh antara lain putih, kuning, jingga, kuning kemerahan, merah, sampai merah tua. Berdasarkan beberapa laporan menyebutkan jagung dengan warna jingga cenderung memiliki kandungan betakaroten tinggi, sedangkan berwarna ungu sampai hitam mengandung antosianin.

\section{Phenotyping jagung Madura untuk studi kandungan betakaroten}

Untuk tujuan studi hubungan warna dengan kandungan antosianin, dilakukan pengambilan 10 aksesi jagung dengan pertimbangan tidak adanya pengaruh metaksania. Jagung yang terpilih adalah jagung yang memiliki gradasi warna mulai dari putih sampai merah keunguan. Phenotyping dilakukan menggunakan pendekatan imaging menggunakan program ImageJ sesuai dengan metode yang dikembangkan oleh Nugroho (2018). Pengambilan gambar dilakukan di studio mini dengan perangkat kamera Fuji Film Fineplix S2980 mode manual dengan exposure F 4.0, shutter speed 40, dan ISO100. Pencahayaan studio mini menggunakan lampu Phillips 9 watt sebanyak dua buah dengan jarak pengambilan ke objek secara vertical $40 \mathrm{~cm}$.

Kisaran nilai untuk peubah RGB jagung berwarna putih yaitu pada jagung M1 dan M7 masing-masing adalah 38.7-53.8 dan 38.22-47.2, sedangkan untuk peubah R,G, dan B masing masing adalah 50.4-71.3, 50.4-75.7, 34.8-49.6 untuk M1, dan 49.0-64.4, 49.0-64.4, 33.8-53.8 untuk M7. Untuk jagung berwarna kuning sampai jingga diwakili oleh M6, M5, M11, dan M2, dengan kisaran nilai RGB masingmasing adalah 20.5-32.5, 17.9-30.9, 15.6-26.2, dan 10.0-7.0. Peubah R,G,B untuk jagung berwarna kuning sampai jingga adalah 42.7-58.6, 26.8-45.0, 6.0-19.8 untuk M6, 38.8-52.6, 20.5-39.7, 6.3-20.0 untuk M5, 36.0-54.3, 14.9-33.8, 6.9-18.3 untuk M5, 36.0-54.3, 14.9-33.8, 6.9-18.3 untuk M11, dan 30.0-37.8, 11.0-17.4, 6.3-9.8 untuk M2 


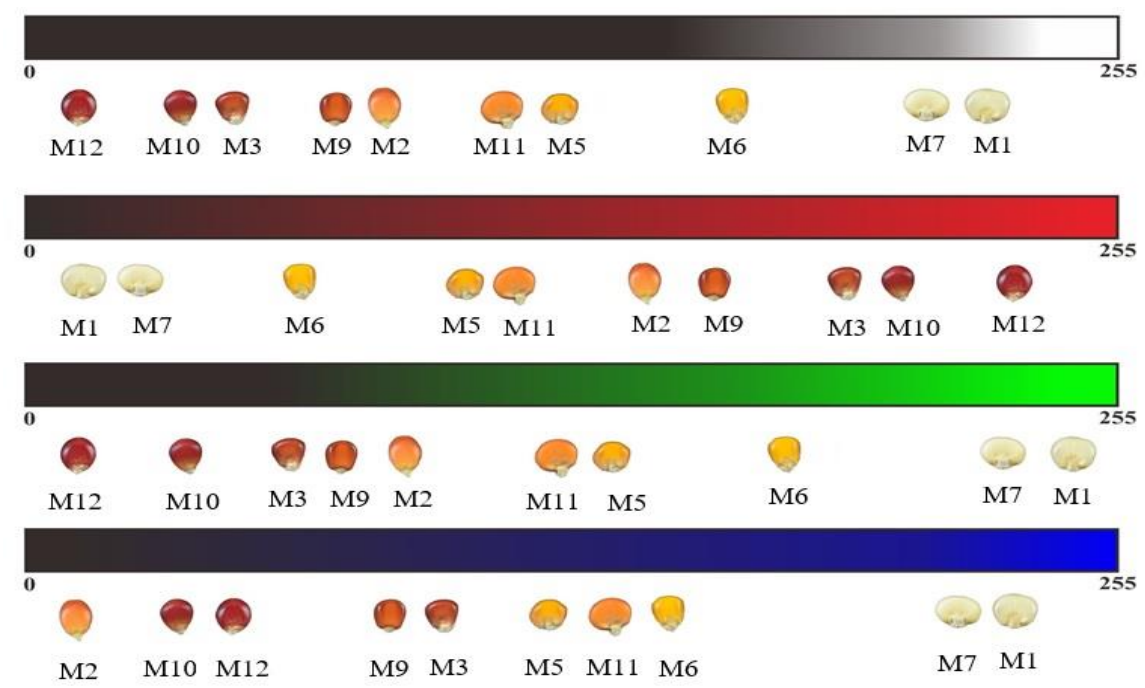

Gambar 4. Ragam warna biji jagung populasi studi betakaroten pada slider RGB

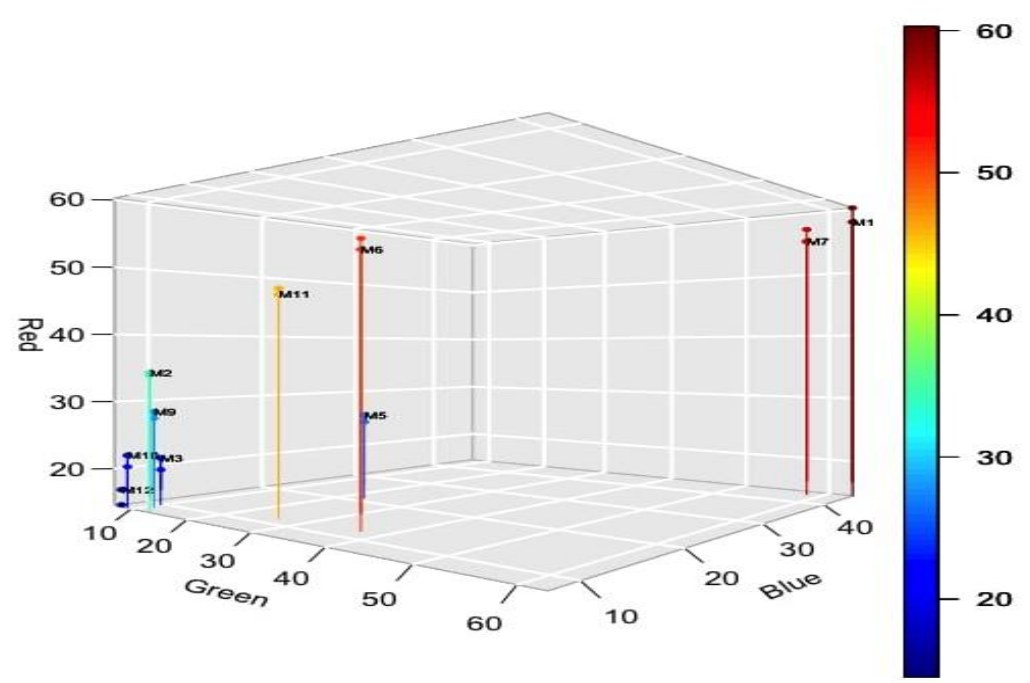

Gambar 1. 3D histogram pada peubah green, blue, dan red

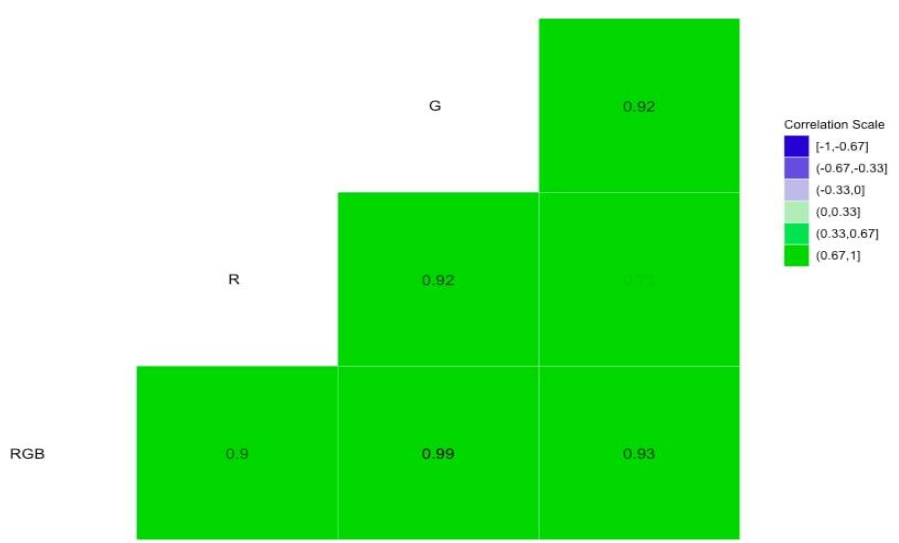

Gambar 2. Corrplot RGB, red, green, dan blue biji jagung pada populasi studi betakaroten 
Pada jagung berwarna merah sampai merah tua diwakili oleh M9, M3, M10, dan M12 dengan kisaran nilai RGB masing-masing 10.6-22.3, 8.0-14.3, 8.2-11.5, 10.0-7.0 (Tabel a). Pada peubah R, G, dan B jagung berwarna merah sampai merah tua memiliki nilai masing-masing sebesar 23.7-37.3, 7.6-22.2, 6.4-19.2 untuk M9, 14.1-28.8, 6.6-14.2, 7.5-12.8 untuk M3, 16.1-24.1, 5.6-10.7, 5.4-8.7 untuk M10, dan 12.6-17.2, 5.1-9.4, 6.4-10.0 untuk M12. Hasil ini menunjukkan bahwa penggunaan teknologi imaging untuk mengkuantifikasi warna jagung berdasarkan parameter $\mathrm{RGB}, \mathrm{R}, \mathrm{G}$, dan B menggunakan perangkat ImageJ mampu membedakan gradasi warna pada masing-masing warna biji jagung. Jagung yang memiliki warna lebih cerah akan memiliki nilai yang lebih tinggi dibandingkan jagung yang memiliki warna lebih gelap. Konsistensi ini terlihat pada slider RGB, di mana peubah RGB, dan R memiliki urutan warna jagung sama. Perubahan posisi M2 pada slider $G$ dan B lebih disebabkan karena karakter warna bijinya yang merupakan perpaduan merah tua dan jingga, sehingga pada slider $\mathrm{G}$ bergeser, dan pada slider $\mathrm{B}$ menjadi yang paling rendah.

Berdasarkan 3D histogram pada Gambar 10. M1 dan M2 cenderung berada pada posisi yang berbeda dibandingkan populasi lainnya. Hal tersebut dikarenakan M1 dan M7 memiliki nilai green, blue, dan red paling tinggi dibandingkan populasi lainnya. Dua jagung tersebut juga memiliki warna dasar sama yaitu putih. Kelompok jagung kuning juga berada pada kelompok yang sama pada 3D histogram, kecuali pada M2. Hal ini dikarenakan M2 memiliki nilai green paling rendah dibandingkan semua populasi yang ada. Untuk populasi jagung berwarna merah sampai merah tua berkumpul pada titik yang sama. Berdasarkan hasil 3D histogram ini juga menunjukkan konsistensi hasil kuantifikasi warna biji jagung melalui pendekatan imaging menggunakan perangkat ImageJ. Nilai dari kelompok RGB mencerminkan kepekatan masingmasing warna dasar dari objek yang di amati. Pengamatan karakter warna biji secara kuantitatif ini diharapkan mampu memberikan informasi mengenai kandungan betakaroten maupun antosianin yang sangat erat kaitannya dengan warna pada biji jagung. Pengetahuan dasar mengenai dasar warna ini dapat dijadikan salah satu pijakan untuk melakukan program biofortifikasi jagung untuk tujuan peningkatan nilai tambah gizi dari jagung yang akan dikembangkan.

Nilai korelasi antar peubah kuantitatif warna menunjukkan korelasi yang positif dan sangat nyata (0.90.99), sedangkan korelasi antar red dan blue adalah nyata dan positif (0.73). Hal ini menunjukkan semakin tinggi peubah kuantitatif warna akan menyebabkan peningkatan peubah kuantitatif warna yang lain. Hal ini disebabkan nilai RGB merupakan nilai rata-rata dari ketiga nilai peubah yang dimasukkan. Hal ini sesuai dengan hasil penelitian Nugroho (2018) yang menunjukkan korelasi positif dan nyata pada peubah kuantitatif warna pada jagung manis.

\section{Phenotyping jagung Madura untuk studi kandungan antosianin}

Kisaran nilai untuk peubah RGB jagung berwarna putih yaitu pada jagung M1 dan M7 masing-masing adalah 38.7-53.8 dan 38.22-47.2, sedangkan untuk peubah R,G, dan B masing masing adalah 50.4-71.3, 50.4-75.7, 34.8-49.6 untuk M1, dan 49.0-64.4, 49.0-64.4, 33.8-53.8 untuk M7. Untuk jagung berwarna kuning sampai jingga nilai kisaran R, G, dan B yaitu M13, M21,M8, dan M15 adalah 58.5-50.3, 34.6-45.0, 11.1-19.8 untuk M13, 47.2-59.4, 11.1-23.8, 6.510.6 untuk M21, 40.8-53.8, 25.5-40.8, 7.3-18.9 untuk M8, 44.7-57.8, 28.2-42.0, 7.9-19.4 untuk M15. Sedangkan untuk jagung berwarna merah sampai merah tua diwakili oleh M18, M16, M20 dan M14 dengan nilai kisaran R, G, dan B masing-masing yaitu 30.0-44.0, 30.0-44.0, 11.0-23.8, 6.510.7 untuk M18, 27.3-33.4, 13.4-18.7, 9.6-7.5 untuk M16, 23.3-33.4, 8.7-12.8, 6.6-9.3 untuk M20, dan 11.7-27.2, 5.414.8, 6.2-12.8 untuk M14.

Hasil pendekatan teknologi imaging untuk mengkuantifikasi warna jagung berdasarkan parameter RGB, R, G, dan B terlihat konsisten. Hasil kuantifikasi untuk populasi studi betakaroten maupun antosianin di sini mampu membedakan masing-masing jagung berdasarkan kepekatan warnanya. Jagung berwarna cerah akan memiliki nilai RGB, R, G, dan B tinggi, sedangkan jagung berwarna gelap akan memiliki nilai yang lebih rendah. Konsistensi terlihat dari slider RGB pada Gambar, di mana pertukaran posisi hanya terjadi antara jagung M15 dan 18 pada peubah G.

Tabel 1. Kisaran nilai setiap warna biji jagung setiap peubah pada populasi studi antosianin

\begin{tabular}{lllll}
\hline & \multicolumn{1}{c}{ RGB } & \multicolumn{1}{c}{$\mathrm{G}$} & \multicolumn{1}{c}{$\mathrm{B}$} \\
\hline M1 & $53.8-38.7$ & $50.4-71.3$ & $50.4-75.7$ & $34.8-49.6$ \\
M7 & $38.2-47.2$ & $49.0-64.4$ & $49.1-67.7$ & $33.8-53.8$ \\
M8 & $20.8-29.9$ & $40.8-53.8$ & $25.5-40.8$ & $7.3-18.9$ \\
M13 & $26.1-34.4$ & $58.5-50.3$ & $34.6-45.0$ & $11.1-19.8$ \\
M14 & $7.7-14.9$ & $11.7-27.2$ & $5.4-14.8$ & $6.2-12.8$ \\
M15 & $22.1-29.4$ & $44.7-57.8$ & $28.2-42.0$ & $7.9-19.4$ \\
M16 & $12.5-15.6$ & $27.3-33.4$ & $13.4-18.7$ & $9.6-7.5$ \\
M18 & $13.2-20.0$ & $30.0-44.0$ & $11.0-23.8$ & $6.5-10.7$ \\
M20 & $11.4-15.2$ & $23.3-33.4$ & $8.7-12.8$ & $6.6-9.3$ \\
M21 & $23.5-31.2$ & $47.2-59.4$ & $11.1-23.8$ & $6.5-10.6$ \\
\hline
\end{tabular}




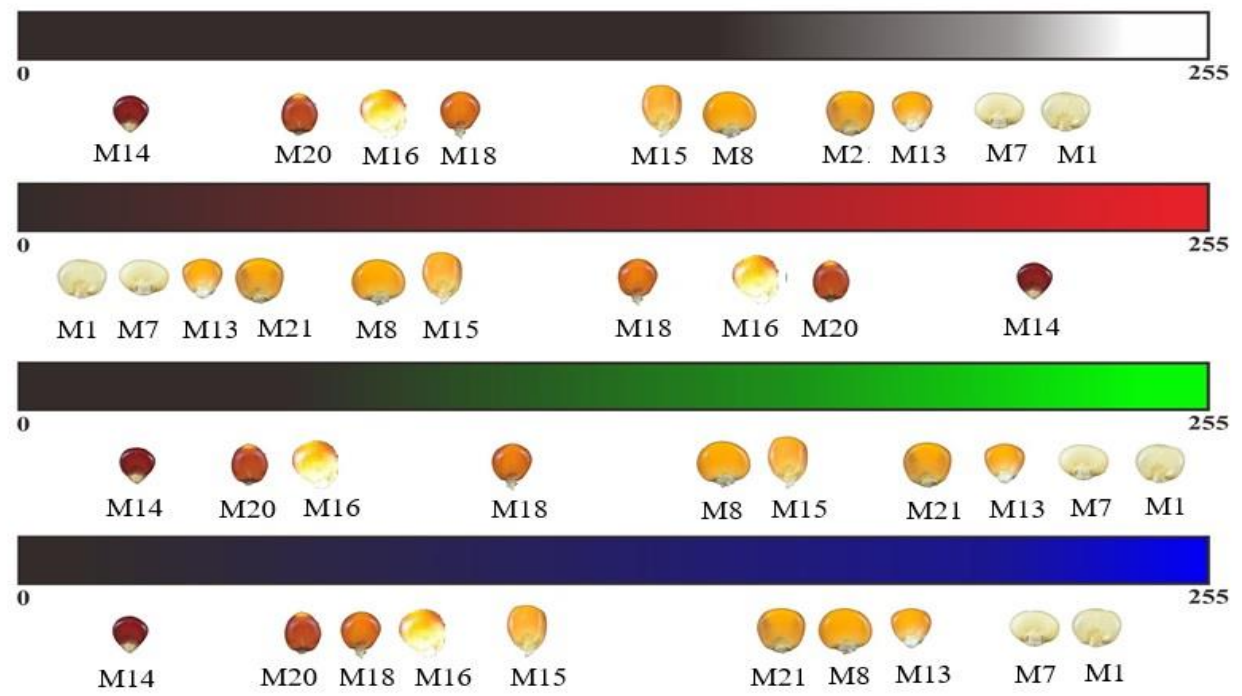

Gambar 7. Ragam warna biji jagung populasi studi antosianin pada slider RGB

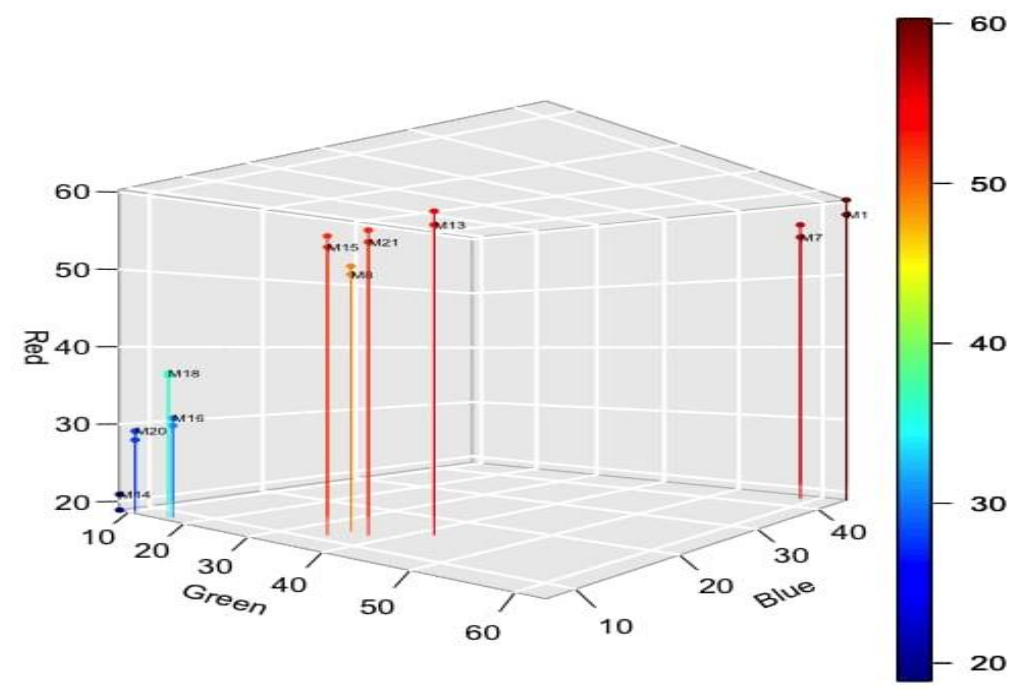

Correlation

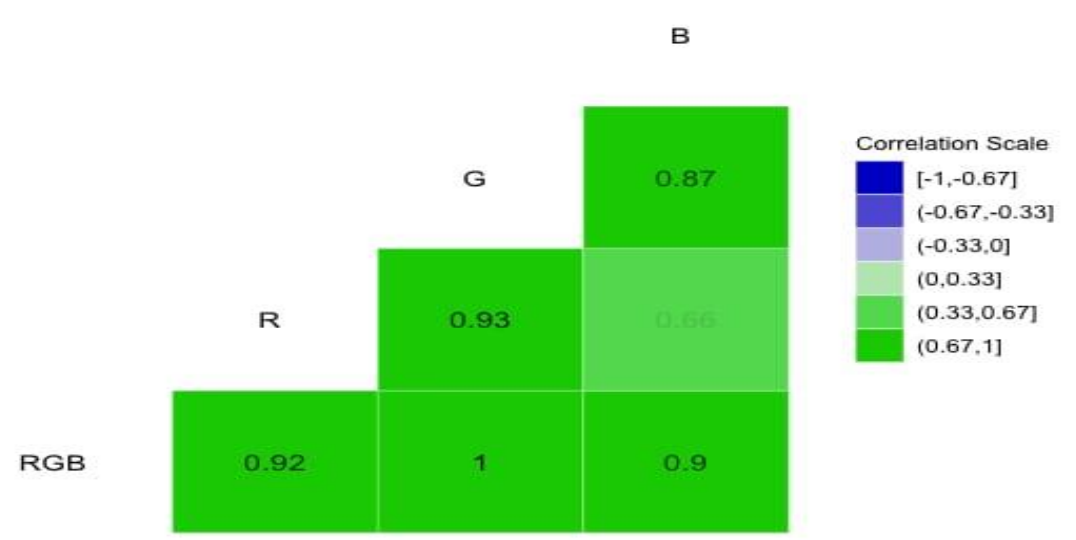

Gambar 8. Corrplot RGB, red, green, dan blue biji jagung pada populasi studi antosinin 


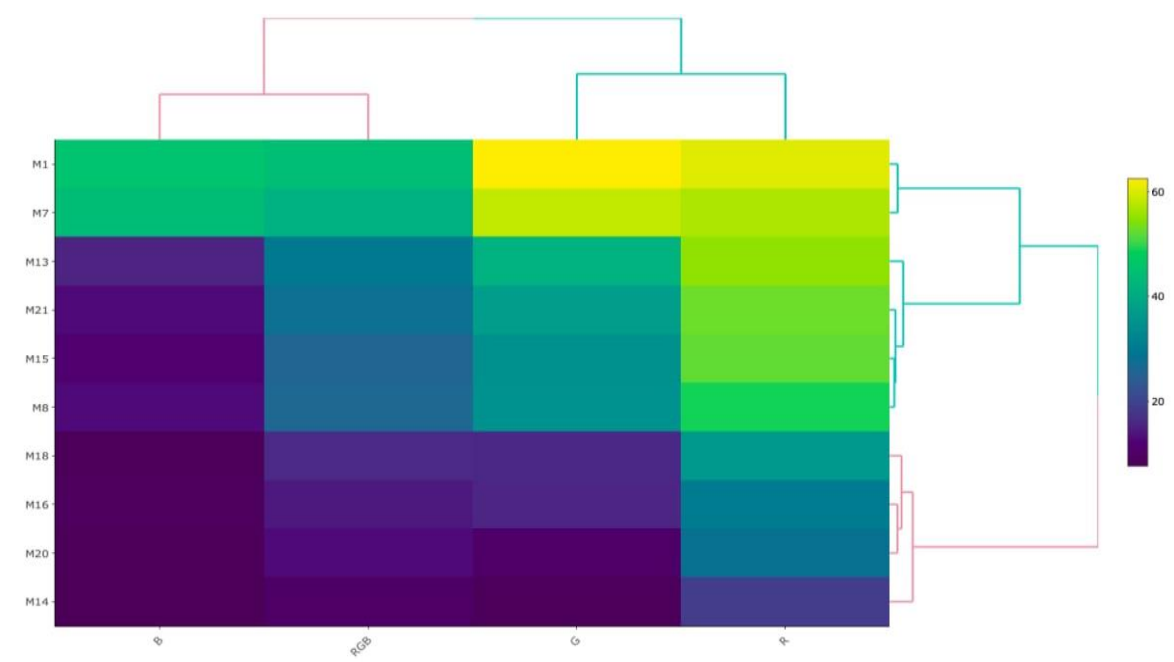

Gambar 9. Analisis clustergram populasi jagung untuk studi antosianin

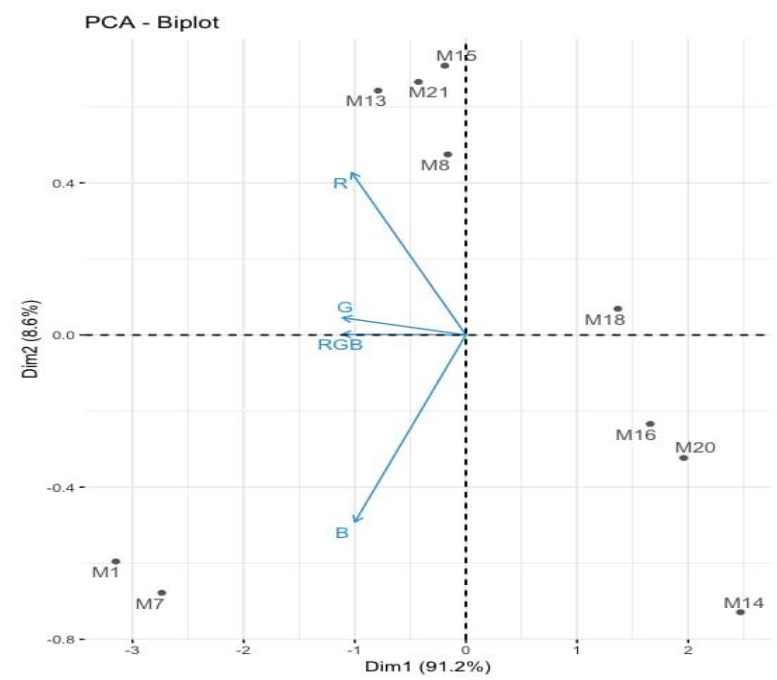

Gambar 10. Hasil analisis biplot beberapa jagung lokal Madura berdasarkan karakter warna

Berdasarkan 3D histogram pada Gambar 10. M1 dan M2 cenderung berada pada posisi yang berbeda dibandingkan populasi lainnya. Hal tersebut dikarenakan M1 dan M7 memiliki nilai green, blue, dan red paling tinggi dibandingkan populasi lainnya. Dua jagung tersebut juga memiliki warna dasar sama yaitu putih. Meskipun M13, M21, M15, dan M8 memiliki nilai R yang tinggi dan mirip dengan jagung putih, namun kelompok kuning sampai jingga tersebut memiliki nilai B yang cukup rendah sehingga kelompok kuning sampai jingga membentuk kelompok tersendiri. Jagung berwarna merah sampai merah tua juga membentuk kemlompok tersendiri yang berdarkan nilai $\mathrm{R}$, $\mathrm{G}, \mathrm{B}$ mereka yang rendah.

Nilai korelasi antar peubah kuantitatif warna menunjukkan korelasi yang positif dan sangat nyata $(0.87$ -
1), sedangkan korelasi antar red dan blue adalah nyata dan positif (0.66) (Gambar 10). Hal ini menunjukkan semakin tinggi peubah kuantitatif warna akan menyebabkan peningkatan peubah kuantitatif warna yang lain. Hal ini disebabkan nilai RGB merupakan nilai rata-rata dari ketiga nilai peubah yang dimasukkan. Hasil korelasi pada populasi studi antosianin ini juga sama dengan hasil korelasi pada populasi studi betakaroten.

$$
\text { Melalui analisis clustergram dilakukan }
$$
pengelompokan jagung berdasarkan nilai RGB, R, G, dan B. Berdasarkan Gambar diketetahui terdapat dua jenis dendogram yaitu dendogram genotipe yang bertindak sebagai baris dan dendogram warna sebagai kolom. Pada dendogram warna dikelompokkan menjadi dua kelompok, kelompok pertama berisi B dan RGB, sedangkan kelompok 
kedua berisi $\mathrm{G}$ dan R. Pengelompokan ini berdasarkan hubungan timbal balik antar karakter warna tersebut dengan genotipe uji (Yuan et al. 2016).

Pada pengelompokan jagung berdasarkan karakter warna, diperoleh tiga kelompok yaitu kelompok I yang berisi jagung berwarna putih (M1 dan M7), Kelompok II berisi jagung berwarna kuning sampai merah cerah (M8, M18, M15, M21), sedangkan kelompok terakhir berisi jagung berwarna merah sampai merah tua (M14, M20, M16, M18). Hasil analisis clustergram ini juga sesuai dengan hasil 3D histogram yang membagi populasi jagung menjadi tiga kelompok.

Menurut Sujiprihati et al. (2006) pengelompokan yang terbentuk pada analisis cluster dapat diketahui dalam dua dimensi menggunakan analisis biplot (Gambar ). Dari hasil analisis diketahui bahwa keragaman yang diterangkan oleh sumbu I sebesar $91.2 \%$ dan sumbu II sebesar $8.6 \%$. Secara keseluruhan keragaman dapat diterangkan sebesar 9.98\%. Hasil analisis biplot juga membagi populasi ke dalam tiga kelompok. Kelompok pertama adalah jagung berwarna putih (M1 dan M7) yang berada di sumbu B, yang menunjukkan bahwa kelompok tersebut memiliki nilai tertinggi pada peubah B. kelompok kedua adalah kelompok jagung berwana kuning sampai jingga yang berada di dekat sumbu R. Hal tersebut menandakan bahwa nilai tertinggi dari kelompok tersebut adalah R. Kelompok ketiga adalah kelompok jagung berwarna gelap, kelompok tersebut cenderung menyebar dan manjauhi sumbu RGB, R, G, dan B. Hal tersebut cukup beralasan karena kelompok tersebut memiliki nilai paling rendah pada semua peubah.

\section{KESIMPULAN}

Kesimpulan yang dapat diambil pada pelaksanaan penelitian ini hingga bulan antara lain: Dari kegiatan eksplorasi diperoleh 60 aksesi jagung lokal, 44 masih dalam bentuk tongkol dan 16 dalam bentuk jagung pipil populasi bulk. Berdasarkan hasil imaging menggunakan perangkat ImageJ untuk populasi studi betakaroten maupun antosianin menunjukkan hasil yang konsisten baik berdasarkan hasil 3D histogram maupun corrplot. Hasil penelitian ini menunjukkan bahwa kuantifikasi warna biji jagung dapat dilakukan melalui pendekatan imaging menggunakan perangkat ImageJ

\section{DAFTAR PUSTAKA}

Abdel-Aal, E. M., Young, J. C. \& Rabalski, I. (2006). Anthocyanincomposition in black, blue, pink, purple, and red cerealgrains. J Agr Food Chem, 54, 4696-470

Burdulis, D., Ivanauskas, L., Dirsè, V., Kazlauskas, S., \& Ražukas, A. (2007). Study of diversity of anthocyanin composition in bilberry (Vaccinium myrtillus L.) fruits. Medicina (Kaunas), 43(12), 971977.

Chandler, K., Lipka, A. E., Owens, B. F., Li, H. L., Buckler, E. S., Rocheford, T., Gore, M. A. (2013). Genetic
Analysis of Visually Scored Orange Kernel Color in Maize. Crop Science, 53, 189-200.

Chaudhary, D. O., Kumar, S., Langyan, S. (2014). Nutritive Value of Maize: Improvement, Applications and Constraints. in Chaudhary DO, Kumar S, Langyan S. Maize Nutrition Dynamics and Novel Uses (eds). New York [US], pp. 3-20

Jittham, O., Fu, X., Xu, J., Chander, S., Li, J., Yang, X. (2017). Genetic Dissection of Carotenoids in Maize Kernels Using High-Density Single Nucleotide Polymorhysm Markers in Recombinat Inbred Population. The Crop Journal, 5, 63-72.

Kumar, S., Sangwan, S., Yadav, R., Langyan, S., Singh, M. (2014). Maize Carotenoid Composition and Biofortification for Vitamin A Activity.in Chaudhary DO, Kumar S, Langyan S. 2014. Maize Nutrition Dynamics and Novel Uses (eds). New York [US], pp. 83-94.

Lee, J., Durst. W., Wrolstad, R. E. (2005). Determination of total monomeric anthocyanin pigment content of fruit juices, beverages, natural colorants, and wines by the $\mathrm{pH}$ differential method: Collaborative study. J AOAC Int, 88, 1269-1278.

Muthusamy, V., Hossain, F., \& Thirunavukkarasu, N. 2015. Develompment of $\beta$-Carotene Rice Maize Hybrids Through Marker-Assisted Introgression of $\beta$-carotene hydroxylase Allele. PLoS ONE, 9(12).

Muthusamy V, Hossain F, Thirunavukkarasu N, Saha S, Agrawal PK, Guleraja SK, Gupta HS. 2015. Genetic Variability and Inter-relationship of Kernel Carotenoids Among Indigenous and Exotic Maize (Zea mays L.) Inbreds. Cereal Research Communications, 43(4), 567-578.

Nugroho, R. A. P. (2018). Pewarisan Bentuk dan Warna Biji pada Jagung Manis dengan Pendekatan Kualitatif dan Kuantitatif. [Disertasi]. Bogor: Institut Pertanian Bogor.

Owens, B. F., Lipka, E., Magallanes-Lundback, M., Tiede, T., Diepenbrock, C.H., Kandianis, C. B., Kim, E., Capela, J., Mateos-Hernandez, M., Buell, C. R., Buckler, E. S., Della Penna, D., Gore, M. A., \& Rocheford, T. (2014). A Foundation for Provitamin A Biofortification of Maize: Genome-Wide Association and Gneomic Prediction Models of Carotenoid Levels. Genetics, 198, 1699-1716.

Rodrigues, V. M., Soengas, P., Landa, A., Ordas, A., \& Revilla, P. (2013). Effects of Celection for Color Intensity on Antioxidant Capacity in Maize (Zea mays L.) Euphytica, 193(3), 339-345. 
Sujiprihati, S., Syukur, M., \& Yunianti, R. (2006). Pewarisan Bentuk dan Warna Biji pada Jagung Manis dengan Pendekatan Kualitatif dan Kuantitatif Analisis Stabilitas Hasil Tujuh Populasi Jagung Manis Menggunakan Metode Additive Main Effect Multiplicative Interaction (AMMI). Bul. Agron., (34)(2), 93-97.

Yuan, J., Murphy, A., Koeyer, D. D., Lague, M., \&
Bizimungu, B. (2016). Effectiveness of the field selection parameters on potato yield in Atlantic Canada. Can. J. Plant Sci., 96, 701-710.

Zilic S, Serpen A, Ak11l1oglu G, Gokmen V, Vancetovic J. 2012. Phenolic Compounds, Carotenoids, Anthocyanins, Antioxidant Capacity of Colored Maize (Zea mays L.) Kernels. Journal of Agric and Food Chem, 60, 1224-1231. 